ORIGINAL PROF-2160

\title{
ESSENTIAL HYPERTENSIVE PATIENTS;
}

\section{Comparison of anti-hypertensive effect of candesartan cilexetil and amlodipine}

\author{
Dr. Shah Nawaz Jamali, Dr. Shahid Ahsan, Dr. Muhammad Jamil Laghari, Dr. Usman Ahmad.
}

ABSTRACT...... Objective: To compare blood pressure lowering effects of angiotensin II type I receptor blocker candesartan cilexetil in comparison with calcium channel blocker amlodipine in essential hypertensive patients. Study design: Randomized, open-labeled, prospective comparative study. Place and duration: The study was carried out in the department of pharmacology and therapeutics, Basic Medical Sciences Institute (BMSI), Jinnah Post Graduate Medical Centre (JPMC), Karachi from July 2007 to January 2008. Subjects and methods: In this study (80) newly diagnosed essential hypertensive patients were enrolled and divided into two groups (DR1) and (DR2) respectively. DR1 patients received candesartan 16mg once a day and DR2 patients received Amlodipine 10mg once a day for 3 months duration. Results: The mean systolic blood pressure of DRI was 162.23 on day 0 which decreased to 141.05 on day 90 , versus DR2 which decreased from 160.12 on day 0 to 140 on day 90 . The mean diastolic blood pressure decreased significantly for DR 1 group from $99.87 \mathrm{mmHg}$ to 87 to 89. mmHg, versus DR2 which decreased from 98.5 to 86.25 . All values of blood pressure have been taken in $\mathrm{mmHg}$. The results of this study were observed statistically significant. Conclusions: Candesartan cilexetil is a newer and safer alternative for the treatment of essential hypertensive patients in comparison to conventional antihypertensive treatment.

Key words: Candesartan cilexetil, Amlodipine, Essential Hypertension, ARBs.

Article Citation

Jamali SN, Ahsan S, Laghari MJ, Ahmad U. Essential Hypertensive Patients; Comparison of anti-hypertensive effect of candesartan cilexetil and amlodipine. Professional Med J 2013;20(3): 354-359.

\section{INTRODUCTION}

Hypertension affects from $20-30 \%$ of world population and is a major cardiovascular risk factor. The relation between cardiovascular risk and blood pressure is continuous, consistent across age groups, present in all ethnic groups, and independent of other risk factors ${ }^{1}$. There is much uncertainty about the pathophysiology of hypertension ${ }^{2}$. A small number of patients between $2-5 \%$ having an underlying renal or adrenal disease as the cause for their raised blood pressure ${ }^{3}$, in the remainder, however no clear single identifiable cause is found and their condition is labeled as "essential hypertension". Progress in understanding the pathogenesis of essential hypertension has been slow because essential hypertension is extremely complex at the molecular level ${ }^{5}$. Various population studies suggest that blood pressure is a continuous variable, with no absolute dividing line between normal and abnormal ${ }^{6}$.

Current international hypertension guidelines (JNC IV) recommended weight control, reduce intake of sodium chloride salt, reduce alcohol consumption and possibly increased dietary intake of potassium as nutritional approaches to prevent and treat hypertension ${ }^{7}$.

Hypertension can cause or is related to various cardiac manifestations, among them left ventricular hypertrophy, congestive heart failure, cardiac dysrhythmias and ischemic heart disease ${ }^{8}$.

The percentage of persons in whom hypertension is controlled is widely viewed as unsatisfactory and may in fact have decreased since $1990^{\circ}$. Little attention has been given to the clinical implications of blood pressure levels observed in persons with poorly controlled hypertension ${ }^{10}$. The benefits of drug intervention in hypertension is to reduce blood pressure are well established, especially in high-risk individuals ${ }^{11}$. The ultimate public health goal of antihypertensive therapy is the reduction of cardiovascular and renal morbidity and mortality ${ }^{12}$. Angiotensin II type I receptor antagonist are relatively a new class of antihypertensive agent ${ }^{13}$. 
Candesartan cilexetil is a potent and selective angiotensin II type I receptor blocker, which binds tightly to and dissociates slowly from ATI receptor. It is administered orally as the pro-drug candesartancilexetil, which is rapidly and completely converted to active compound candesartan, during gastro -intestinal absorption ${ }^{14}$. The selective and competitive binding of candesartan onto the angiotensin II, a key mediator in the rennin-angiotensin system results in significant reductions in systolic and diastolic blood pressure with once daily dosage of $8-16 \mathrm{mg}^{15}$. Among the different classes of drugs that are currently used in the treatment of hypertension calcium channel blockers (CCBs) play a special role because of their specific action on the constrictor tone of the vascular smooth muscle cells ${ }^{16}$.

Among dihydropyridines, amlodipine has been reported as an effective antihypertensive drug associated with regression of left ventricular hypertrophy and vascular hypertrophy, the antiatherogenic and the remodeling effects ${ }^{17}$.

\section{SUBJECTS AND METHODS}

This study was conducted in the department of pharmacology and therapeutics, Basic Medical Sciences Institute (BMSI), in collaboration with the department of medicine, Jinnah Post-graduate Medical Centre, Karachi, from July 2007 to January 2008. Eighty patients with newly diagnosed essential hypertension were initially enrolled in this study after taking informed and written consent, selected from medical OPD of JPMC. Out of these seventy-four patients were associated throughout the study period. Out of remaining six patients four has not come for follow-up in amlodipine group two due to unknown reasons and two patients has complained of lethargy, dizziness, drowsiness and refused to continue the study while two patients were dropped in candesartan group, due to gastric upset and headache. Following patients were included in the study: patients of either sex with newly diagnosed essential hypertension, patients aged between 20 - 70 years, patients having no history of using anti-hypertensive medications. The patients who were excluded from the study: patients having known history of allergy to angiotensin receptor blockers (ARBs) or CCBs, patients having a history of hepatic or renal impairment, pregnant or lactating women, and patients who were already taking antihypertensive treatment. The safety and tolerability were assessed by spontaneous reports of adverse events as observed and reported by the patients and has been shown in table IC.

\section{STUDY DESIGN}

The study period was consisted of 12 weeks (90 days) with weekly follow-up visits of patients; but the observations of the parameters were recorded on day 0 , day 45 and day 90 of the study period. The selected patients were divided into two groups. DR1 (Candesartan cilexetil) and DR2 (Amlodipine). Forty patients with newly diagnosed essential hypertension with the above mentioned criteria were provided Tab. Candesartan $16 \mathrm{mg}$ once a day for 90 days in DR 1 group; while forty patients with newly diagnosed essential hypertension were provided Tab. Amlodipine $10 \mathrm{mg}$ once daily for 90 days in DR2 group. Following parameters were observed during study period, systolic blood pressure (SBP), diastolic blood pressure (DBP) and safety profile of the patients.

\section{RESULTS}

The values are expressed in mean \pm SEM (standard error of mean). ANOVA was applied as a test of significance to observe the statistical significance of this comparative research project. A $p$-value of $\leq 0.05$ was considered statistically significant. Out of 40 patients on day 0,38 patients were treated with DR 1 till day 90. Mean systolic B.P. on day 0 was 162.23$\pm 2.12 \mathrm{mmHg}$, which decreased to $148.68 \pm 1.49$ $\mathrm{mmHg}$ on day 45 and $141.05 \pm 1.14 \mathrm{mmHg}$ on day 90. This decrease in systolic B.P was observed statistically significant $(P<0.001)$, when compared between day 0 and day 90 , as shown in Table-I $A$ and 
fig. 1A.

Out of 40 patients on DR2, 36 patients were treated till day $90^{\text {th }}$. The mean systolic B.P decreased from $160.12 \pm 2.0 \mathrm{mmHg}$ on day 0 to $147.08 \pm 1.45$ $\mathrm{mmHg}$ on day 45 and $140 \pm 1.23 \mathrm{mmHg}$ on day $90^{\text {th }}$ of the treatment. This reduction was found statistically significant $(p<0.001)$, as shown in table-I A and figure $1 \mathrm{~A}$.

Both Candesartan cilexetil and Amlodipine decreased the mean diastolic B.P. In DR1 group mean diastolic B.P on day 0 was $99.87 \pm 0.81 \mathrm{mmHg}$ which decreases to $93.28 \pm 0.71 \mathrm{mmHg}$ on day 45 and $87.89 \pm 0.67 \mathrm{mmHg}$ on day $90^{\text {th }}$ of the treatment. This decrease in diastolic B.P was found statistically significant with a $P$-value $(P<0.001)$ while in case of DR2 group mean diastolic B.P was decreased from $98.5 \pm 0.61 \mathrm{mmHg}$ on day 0 to $91.38 \pm 0.67 \mathrm{mmHg}$ on day 45 and $86.25 \pm 0.60 \mathrm{mmHg}$ on day $90^{\text {th }}$ of the treatment. This decrease was also observed statistically significant as depicted in table-I B and figure $1 \mathrm{~B}$.

\begin{tabular}{|c|c|c|c|c|}
\hline Groups & Day - 0 & Day - 45 & Day - 90 & P-value \\
\hline DR 1 & $\begin{array}{c}162.23 \\
+2.12 \\
(40)\end{array}$ & $\begin{array}{c}148.68 \\
+1.49 \\
(38)\end{array}$ & $\begin{array}{c}141.05 \\
+1.14 \\
(38)\end{array}$ & $<0.001$ \\
\hline DR 2 & $\begin{array}{c}160.12 \\
+2.0 \\
(40)\end{array}$ & $\begin{array}{c}147.08 \\
+1.45 \\
(36)\end{array}$ & $\begin{array}{c}140 \\
+1.23 \\
(36)\end{array}$ & $<0.001$ \\
\hline
\end{tabular}

Table-I-A. Comparison of mean systolic B.P from Day 0 Day 90, of the treatment with DR 1, DR 2 in essential hypertensive patients

Values are expressed in mean \pm SEM. ANOVA was applied as a test of significance. A p-value of $\leq 0.05$ was considered statistically significant. DR1 (Candesartan cilexetil), DR 2 (Amlodipine). All observations are in $\mathrm{mmHg}$.

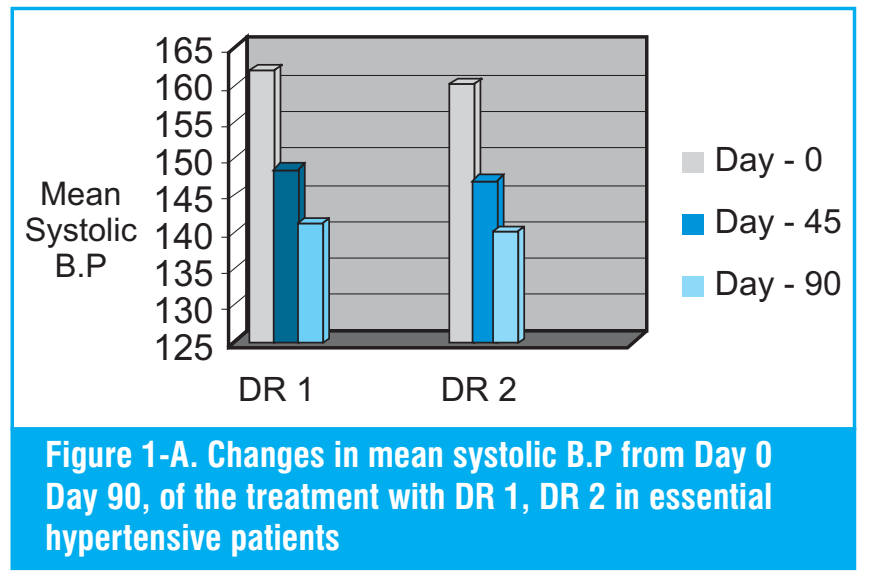

\begin{tabular}{|c|c|c|c|c|}
\hline Groups & Day - 0 & Day - 45 & Day - 90 & P-value \\
\hline DR 1 & $\begin{array}{c}99.87 \\
\pm 0.85\end{array}$ & $\begin{array}{c}93.28 \\
\pm 0.71\end{array}$ & $\begin{array}{c}87.89 \\
\pm 0.67\end{array}$ & $<0.001$ \\
& $(40)$ & $(38)$ & $(38)$ & \\
\hline DR 2 & 98.5 & 91.38 & 86.25 & \pm 0.61 \\
& $\begin{array}{c} \pm 0.67 \\
(40)\end{array}$ & $\begin{array}{c} \pm 0.60 \\
(36)\end{array}$ & $<0.001$ \\
Table-I B. Comparison of mean diastolic B.P from Day 0 \\
Day 90 of the treatment with DR 1 \& DR 2 in essential \\
hypertensive patients
\end{tabular}

Values are expressed in mean \pm SEM. ANOVA was applied as a test of significance. A $p$-value of $\leq 0.05$ was considered statistically significant. DR1 (Candesartan cilexetil), DR 2 (Amlodipine). All observations are in $\mathrm{mmHg}$.

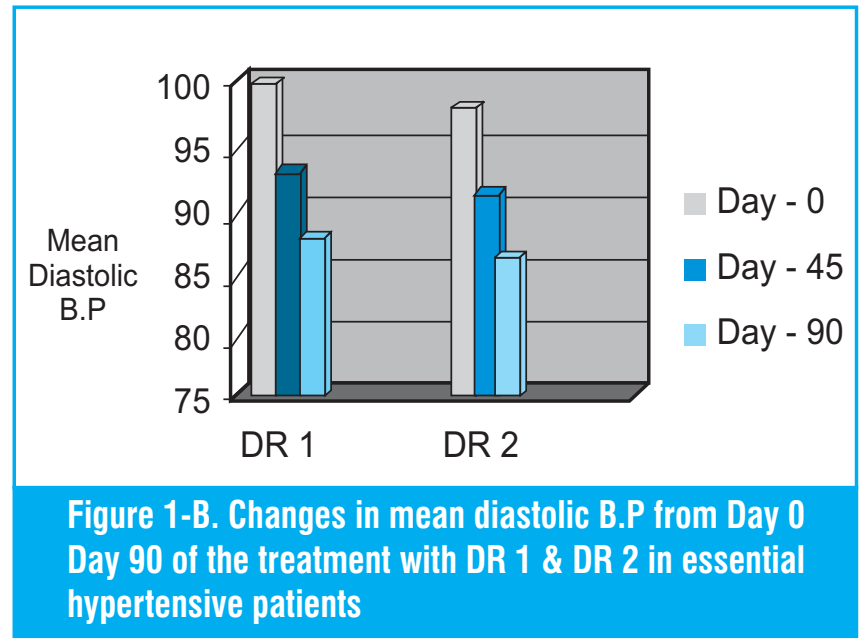




\begin{tabular}{|c|c|c|}
\hline SIDE EFFECTS & ADESARTAN CILEXETIL & AMLODIPINE \\
\hline Drowsiness & 0 & $01(2.6 \%)$ \\
\hline Constipation & 0 & $02(5.26 \%)$ \\
\hline Headache & $01(2.7 \%)$ & $01(2.6 \%)$ \\
\hline Dizziness & 0 & $02(5.26 \%)$ \\
\hline Abdominal pain & $01(2.7 \%)$ & 0 \\
\hline Backache & $01(2.7 \%)$ & 0 \\
\hline Edema & $01(2.7 \%)$ & 0 \\
\hline Nausea / Vomiting & 0 & $01(2.6 \%)$ \\
\hline Total Patients & $\mathbf{0 4}(\mathbf{1 0 . 8} \%)$ & $\mathbf{0 7}(\mathbf{1 8 . 4 \% )}$ \\
\hline
\end{tabular}

Table-I C. Frequency of observed and reported side

effects with DR1 \& DR2 in essential hypertensive patients Indicate the \%age from total reactions

\section{DISCUSSION}

In this comparative research study the aim was to observe the efficacy and safety profile of essential hypertensive patients. This study demonstrates significant changes in blood pressure lowering effects with both Candesartan cilexetil and Amlodipine in essential hypertension. Present study revealed that candesartan cilexetil and amlodipine has significantly reduced the mean systolic and diastolic B.P in essential hypertensive patients. The results of both drug groups have shown statistically significant reduction with a $P$ - value $(P<0.001)$. The literature search revealed that clinical trial was conducted by Cardiologia and his associates in 2005 and mentioned that angiotension receptor blockers like Candesartan cilexetil and losartan are effective in controlling blood pressure. In 2006, Asmar et al conducted a comparative multicentre research project to observe the efficacy of (ARBS) in long-term control of systolic blood pressure in essential hypertensive patients. Bonner $G$ and his research fellows carried out a pilot research project to find out an angiotension receptor blocker with prolonged duration of action; his research observations were that Candesartan cilexetil is a long acting antihypertensive compound in comparison to other angiotension receptor antagonists.

In 2004, a research study was conducted by Rashid et al at JPMC to compare blood pressure lowering effects between Atenolol and amlodipine in essential hypertensive patients. Similarly Hoshide et al in 2005 and Ishimtuu in japan conduted their research pilot studied to compare blood pressure lowering effects between calcium channel blockers and angiotension receptor antagonists to find out their efficacy and safety profile. The results of our DR1 group are in accordance with the research clinical trials of cardiologia et al (2005), ${ }^{18}$ Asmar et al $(2006)^{19}$ but slightly differ from the results of Bonner $\mathrm{G}$ et al $2005^{20}$. This difference may be due to the duration of their clinical trials. The result of our DR2 group also matches with the studies conducted by Rashid et al $2004^{21}$. Hoshide $S$ et al 2005, ${ }^{22}$ and Ishimitsu T et al $2005^{23}$. (Where explaination of these references) The tolerability of the two drugs was not quite similar and the incidence of side effects reported by the patients during the whole duration of study was more observed and reported in DR2 group in comparison to DR 1 group.

\section{CONCLUSIONS}

Candesartan Cilexetil is a newer alternative for the treatment of essential hypertension in comparison to conventional anti-hypertensive treatment.

\section{Copyright@ 10 Jan, 2013.}

\section{REFERENCES}

1. Staessen JA, Liyan, Thijs $L$ et al. Blood pressure reduction and cardiovascular prevention: An update including the 2003-2004 secondary prevention trials. Hypertens Res 2005 ; (28): 385-407.

2. Carretero OA and Oparil S. Essential hypertension part 1: Definition and etiology. Circulation 2000; (101): 329-335.

3. Oparil S, Zaman MA, Calhoun A et al. Pathogenesis of hypertension. Ann Intern Med 2003 ; (139): 761-776.

4. Vikrant $S$ and Tiwari SC. Essential hypertension: 
pathogenesis and pathophysiology. JIALM 2001; (02):140-161.

5. Brown MJ. Hypertension and ethnic group. BMJ 2006 ; (332): 833-836.

6. Barriuso RP, Banegas JR, Lawreuce JA et al. Systolic blood pressure, diastolic blood pressure, and pulse pressure: An evaluation of their joint effect on mortality. Ann Intern Med 2003; 139:731-39.

7. Chobanian AV, George LB, Henry RB et al. The seventh report of the joint national committee on prevention, detection and treatment of high blood pressure. JAMA 2003; 289:2560-2572.

8. Frochlich ED, Apstein C, Chobanian AV et al. The heart in hypertension. N Engl J Med $1992 ;$ 115):1004-8.

9. Hyman DJ, Valory N, pavlik K et al. Characteristics of hypertensive patients in the united states. $\mathrm{N}$ Engl $\mathrm{J}$ Med $2001 ;(345): 479-86$.

10. Ramchandan SV, Lorson MG, Leip EP et al. Impact of high-normal blood pressure on the risk of cardiovascular disease. N Engl Med 2001; 345: 1291-97.

11. Dahlof B, Devereux RB, Julius $S$ et al. Cardiovascular morbidity and mortality in the losartan intervention for endpoint reduction in hypertension in hypertension study (LIFE): Arandomized trial against atenolol. Lancet $2002 ;(359): 995-1003$.

12. The seventh report of the joint national committee on prevention, detection, evaluation, and treatment of high blood pressure. JAMA 2002; 289:25602572.

13. Grahaun AG, Receven J, Tarek FT et al. Efficacy of candesartan cilexetil alone or in combination with amlodipine and hydrochlorothiazide in moderate to severe hypertension. J Hyperten 2000 ; (36) 45460.

14. Sever P. Candesartan: A new, long-acting, effective angiotensin II type1 receptor blocker. J Hum Hyperten $2001 ;(02): 91-95$.

15. Easethope SE, and Jarvis B. Candesartan; An update of its use in essential hypertension. Drugs 2002 ; 62):1253-87.

16. Leonetti $G$. Effects of nilvadipine and amlodipine in patients with mild to moderate essential hypertension: Adouble-blind, prospective, randomized clinical trial. Curr Med Res Opin 2005 ;(21): 951958.

17. Schiffrin E and Deng LY. Structure and function of resistance arteries of hypertensive patients treated with a beta-bloker or a calcium channel antagonists. J Hypertens $1995 ;(14): 1247-55$.

18. Cardiologia CD, Volpe M, Morsing P et al. Treatment of systolic hypertension. Spot light on recent studies with angiotensin II antagonists. J Hum Hypertens 2005 ;(19): 93-102.

19. Asmar R. Targeting effective blood pressure control with angiotensin receptor blockers. J Hum Hypertens 2006 ; (33): 315-20.

20. Bonner G and FUCH sw. Long acting blood pressure reduction by candesartan in patients with hypertension. Curr Med Res Opin 2005 ;(21): 93540.

21. Rashid SA. Comparison of amlodipine and atenolol in newly diagnosed essential hypertensive patients. JPMC 2004.

22. Hoshide S, Kario K, Ishikwa J. Comparison of the effects of cilnidipine and amlodipine on ambulatory blood pressure. Hyperten Res 2005 ;(28): 1003-8.

23. Ishimitsu T, Kobayashi T, Honda T et al. Productive effects of an angiotensin II receptor blocker and a long-acting calcium channel blocker against cardiovascular organ injuries in hypertensive patients. Hypertens Res 2005 ; (28): 351-9. 
AUTHOR(S):

1. DR. SHAH NAWAZ JAMALI Assistant Professor Hamdard University Karachi.

2. DR. SHAHID AHSAN

3. DR. MUHAMMAD JAMIL LAGHARI

4. Dr. Usman Ahmad
Correspondence Address:

Dr. Shah Nawaz Jamali

Flat No. B-12, Gallant Summit,

Opposite Sindh Board of Technical Education, Block No. 11

Gulshan-e-lqbal, Karachi.

sjamali74@gmail.com

Mectronic submission saves time, postage costs and allows the manuscript
to be handled in electronic form throughout the publication process.
Accepts electronic submission of articles via e-mail, attachment in
MS Word format at following address:
info@theprofesional.com
editor@theprofesional.com
publication@theprofesional.com
for more details, visit us ;
www.theprofesional.com

